\title{
Engraved in the Landscape: The Study of Spatial and Temporal Characteristics of Field Names in the Changing Landscape
}

\author{
Nadja Penko Seidl
}

Department of Landscape Architecture, University of Ljubljana, Ljubljana, Slovenia

The importance of toponym studies for understanding the relationship between people and the place they inhabit has been emphasized by several studies. Despite the differences in the landscapes' physical character and social relations, similar naming concepts can be found globally. Although toponyms are not visible or tangible, they are one of the most persistent linguistic symbols. As such they reveal much information about a landscape in the time when it was settled and named. The presented research focuses on three aspects of field names - microtoponyms, which in detail describe landscape that is shaped and managed by agriculture. An analysis of historical and contemporary sources offers insight into the temporal dimension of field names; the interconnection between names and named places shows the relation between named places, management practices, and landscape character; and last, an overview of landscape changes and their relationship to the persistence of field names is presented.

KEYWORDS toponym, field name, landscape, landscape character, temporality, persistence, land use change.

\section{Introduction}

\footnotetext{
Once, from eastern ocean to western ocean, the land stretched away without names. Nameless headlands split the surf; nameless lakes reflected nameless mountains; and nameless rivers flowed through nameless valleys into nameless bays.

Men came at last, tribe following tribe, speaking different languages and thinking different thoughts. According to their ways of speech and thought they gave names, and in their generations laid their bones by the streams and hills they had named. But even when tribes
} 
and languages had vanished, some of those old names, reshaped, still lived in the speech of those who followed.

(Stewart [I945] 2008, 3)

Naming is one of the first human activities in any environment, it is the first step toward its domestication, and toward the creation of a landscape out of a sheer physical environment (Tilley I994). Toponyms, positioned between a landscape's physical reality and humans' perception and understanding of that reality, draw the attention of researchers from geography, archaeology, history, ecology, language, linguistics, and many other disciplines. Consequently, the selected approaches, research questions, and methods are very diverse, as are the scale and the detail of the research. Whereas some toponymic researches are focusing on investigating toponyms' characteristics on certain micro location in detail, others are researching naming patterns and similarities among them (Tent 20I5). Furthermore, some studies are focusing solely on collecting and cataloguing the names of places with no reference to named places (Rose-Redwood, Alderman, and Azaryahu 2010), whereas the other stress the wider importance of toponymic research for understanding landscapes, their historical, geographical, and social aspect (Boillat et al. 2013; Conedera et al. 2007).

In spite of the differences in physical environment and social relations, some universal naming concepts exist all over the world. Local people have always named places according to their significance (Boillat et al. 20I3; Miller I969; Tuan I99I), therefore researching the interconnection between names and named places reveals much information about the way people perceived, understood, and adapted the natural environment to their needs.

Two attributes of toponyms which have been emphasized in several studies guided the research, presented in this article: first, their longevity and persistence in continuously changing landscape, and second, the way that they reflect the relation between people and places/landscapes. Toponyms are one of the most conservative elements of every language (Gelling [1978] 20I0; Kadmon 2000), they often survive even in places where spoken language changes (Thornton 1997). Throughout Europe, names of Roman, Celtic, Illyrian, or even Indo-European origin could be found (Gelling [I978] 2010), while many toponyms of Closer and Middle East mentioned in Egyptian documents from the 15 th century BC and the Bible from $\mathrm{I} 2$ th century BC are still being used today (Kadmon 2000). As such, toponyms are an inseparable part of every landscape. As J. Hawkes (200I) emphasized, they are one of the things that link men most intimately with their territory. Toponyms reflect the way people perceived, understood, and adapted the environment to their everyday needs. Motives for naming were not always just utilitarian - whereas some places were used for gathering cattle or growing crops, others were simply "good for thinking” (Basso I996).

The presented research focuses on examining the spatial, as well as temporal, aspect of field names. Research questions have been derived from the results of another research (Penko Seidl 2015), where the interconnection between field names and landscape character has been studied. The results have shown, that named areas represent some sort of spatial units, and that clusters of these units represent landscape character areas. These areas reflect the traditional husbandry organization and management of village land with the combination of: (I) fields, (2) meadows, (3) pastures, and (4) forest. Although 
landscape has changed significantly, research has shown that many field names have been preserved for at least 200 years (for that period, cartographic evidence is available). As such, they have been recognized as a link between past and present landscapes and consequently, as a tool for planning and managing future ones (Penko Seidl 2008; Penko Seidl, Kastelec, and Kučan 2015). The research presented in this article focused on the following aspects:

(I) The temporal dimension of field names and the way they are being preserved or changed throughout time;

(2) The interconnection between names and named places - how landscape character is reflected in names, and if it is possible to define the character of landscape only on the basis of names;

(3) The connection between the first and the second - the way landscape changes are reflected in field names.

\section{Materials and methods}

The study area where field names were collected, mapped, and analyzed are four cadastral communities ${ }^{\mathrm{I}}$ in the plateau of Zgornja Pivka, in southwestern Slovenia (Figure I). The area is approximately 50 square kilometers wide and is characterized by karst terrain, a lack of water, and a relatively harsh climate. One of the most recognizable characteristics of the area is the system of small intermittent lakes, situated on the limestone terrace between valley floor and the ridge of Javorniki. The area has been continuously cultivated since the 6th century. At the beginning of the I9th century (around I 820 when the first detailed cartographic data - Franciscan Cadaster - was made) more than $80 \%$ of the area was cultivated, while nowadays around $60 \%$ is covered by forests. Farming is less profitable, so fields are changing into meadows, while former areas of village commons have been either forested or naturally overgrown by forest.

Four data sources were used to collect field names and analyze their spatial and temporal characteristics:

(I) Historical: (a) maps of the Franciscan Cadaster (see note I) from around I820 (scale I:2880), and the so-called (b) Protokoll der Grundparcellen of the Franciscan Cadaster (a list of all parcels, which contains some field names).

(2) Contemporary: (a) basic topographic plan (scale r:5000) and (b) local informants - mostly farmers and foresters who knew the majority of field names within their local community.

After field names were collected, field name lists and maps were prepared. For two sources: maps of Franciscan Cadaster and topographic plan, field names were transcribed on the same coordinates as they appeared on original maps. The other two sources: Protokoll der Grundparcellen and local informants, enabled us to delineate areas, described by a single field name. For each group of parcels characterized by a field name, a new attribute - called field name unit $^{2}$ - was added to the digital cadastral plan. ArcGIS was used for preparing all cartographic databases. Five hundred and seventy-three different toponyms were collected from all four data sources. To answer research questions, raised in the Introduction, the following analyses have been made: 
(I) A comparison between names on historical and contemporary sources was made to answer the question on temporal "behavior" of field names;

(2) Spatial characteristics of similar field names were compared to discuss the relationship between landscape character and field names;

(3) Names where naming motifs are derived from land use have been selected from the comprehensive list of field names, and land use in two different periods was compared to answer the question how land use change is reflected in field names.

\section{Results and discussion}

\section{The temporality of field names}

Despite the facts that landscape continuously changes and that many field names are not recorded on maps, but preserved through oral tradition, they proved to be quite persistent. This research has shown that local informants possess the most detailed knowledge about the field names - the list of field names provided by local informants was the most comprehensive (see Table I). The second most comprehensive source is Franciscan Cadaster map: two hundred and fourty-eight toponyms were listed there. But considering the facts: (I) that not all the names which are being used nowadays are recorded on contemporary maps, (2) that people were more strongly dependent on the landscape in the beginning of the I9th century, and ( 3 ) the fact that cartographers ${ }^{3}$ were foreigners who - in most cases - did not speak the language of local inhabitants, we can infer that not all the names which were used among locals at the beginning of the I9th century were recorded on the Franciscan Cadaster. The comparison of identical names, recorded on historical and contemporary sources has shown that 6I names appear at least on one historical, and on one contemporary source in completely identical form, whereas 27 names appear on all four data sources (Table 2). The spelling of the names on Franciscan Cadaster is different, while the Slovene names were recorded in German form, but the pronunciation is identical. These names are a proof of longevity of field names. They have "survived" the shift of five different states/political systems (Austrian Empire, Austrian-Hungarian Empire, Italian Kingdom, Yugoslavia, and Slovenia), three different official languages (German, Italian, and Slovene), and significant changes in land use. Another interesting aspect, which should be mentioned in this context, is the fact that, as shown

TABLE 1

NUMBER OF FIELD NAMES, COLLECTED WITH ALL FOUR SOURCES

\begin{tabular}{|c|c|c|c|c|c|c|c|c|c|}
\hline \multirow[t]{2}{*}{$\begin{array}{l}\text { Cadastral } \\
\text { community }\end{array}$} & \multirow[t]{2}{*}{$\begin{array}{l}\text { Local in- } \\
\text { formants }\end{array}$} & \multirow{2}{*}{$\begin{array}{l}\text { Topo- } \\
\text { graphic } \\
\text { map }\end{array}$} & \multirow{2}{*}{$\begin{array}{l}\text { Protokoll } \\
\text { der Grund- } \\
\text { parcellen }\end{array}$} & \multirow{2}{*}{$\begin{array}{l}\text { Franciscan } \\
\text { Cadastre - } \\
\text { map }\end{array}$} & \multirow{2}{*}{$\begin{array}{l}\text { Sum of } \\
\text { different } \\
\text { toponyms }\end{array}$} & \multicolumn{4}{|c|}{$\begin{array}{l}\text { Repetition of toponym } \\
\text { on different data sources }\end{array}$} \\
\hline & & & & & & $1 x$ & $2 x$ & $3 x$ & $4 x$ \\
\hline Jurišče & 42 & 23 & 9 & 46 & 89 & 69 & 14 & 3 & 3 \\
\hline Palčje & 103 & 89 & 15 & 70 & 179 & 98 & 68 & 9 & 4 \\
\hline Parje & 91 & 74 & 20 & 55 & 149 & 86 & 45 & 6 & 12 \\
\hline Zagorje & 71 & 56 & 30 & 77 & 156 & 104 & 33 & 12 & 7 \\
\hline sum* & 307 & 242 & 74 & 248 & 573 & 357 & 160 & 30 & 27 \\
\hline
\end{tabular}

*Place names, church names, and names of some other artifacts were also recorded. While they present only a small part of all collected names, they were not excluded from further analysis. 
TABLE 2

FIELD NAMES, WHICH WERE RECORDED ON ALL FOUR DATA SOURCES

\begin{tabular}{|c|c|c|c|c|}
\hline \multirow[b]{2}{*}{ Cadastr. comm. } & \multicolumn{2}{|c|}{ Contemporary data sources } & \multicolumn{2}{|c|}{ Historical data sources } \\
\hline & Local informants & Topographic map & $\begin{array}{l}\text { Franciscan } \\
\text { Cadastre - Pro- } \\
\text { tokoll der Grund. }\end{array}$ & $\begin{array}{l}\text { Franciscan } \\
\text { Cadastre - map }\end{array}$ \\
\hline Jurišče & JURŠČE* & JURIŠČE & DORF...JURSITS & JURSCHITSCH \\
\hline Jurišče & Kršičevec & Kršičevec & Krasizouz & Kraschizovatz \\
\hline Jurišče & Ulovke & Ulovka & Ulake & Ulake \\
\hline Palčje & Pod Hribom & Pod Hribom & Pod Hribom & Pod Hribom \\
\hline Palčje & Primožca & Primožca & Primasche & Primasche \\
\hline Palčje & Solne & Solne & Soline & Soline \\
\hline Palčje & Sv. Marjeta & Sv. Marjeta & Santa Marieta & St. Margeritha \\
\hline Parje & Malo drskovško jezero & Malo drskovško jezero & Mala Isira & mala Isira \\
\hline Parje & Veliko drskovško jezero & Veliko drskovško jezero & Velika Isira & Velika Isira \\
\hline Parje & Kamence & Kamence & Kamenze & Kamenze \\
\hline Parje & Lokavščice & Lokavščice & Lokauza & Lokauze \\
\hline Parje & Prašnice & Prašnice & Prasenza & Prasenza \\
\hline Parje & Kraške rebri & Kraške rebri & O Kraske Reber & o Krasker Rebar \\
\hline Parje & Rosopasi & Rosopas & Resopas & Resopas \\
\hline Parje & Snnočice & Snočice & Snotzhizhe & Snozhize \\
\hline Parje & Ščitnice & Ščitnice & Schittenze & Schittenze \\
\hline Parje & Topelca & Topelca & Tupelza & Tupelzo \\
\hline Parje & Volarija & Volarija & Vollaria & Vollaria \\
\hline Parje & Vrhki & Vrhki & Verhek & Verhek \\
\hline Parje & Žlebi & Žlebi & Slebech & Schlebi \\
\hline Zagorje & Gradišče & Gradišče & Gradische & Gradischtsche \\
\hline Zagorje & Malo zagorsko jezero & Malo zagorsko jezero & Mali Isero & Mali Isero \\
\hline Zagorje & Njivice & Njivice & Nivize & Nivize \\
\hline Zagorje & Prekopnice & Prekopnice & Prekopenze & Prekopeze \\
\hline Zagorje & Zadove & Zadolc & Sa Douzam & Sadouzam \\
\hline Zagorje & ZAGORJE & ZAGORJE & SAGURIE & SAGURIE \\
\hline Zagorje & Zevniki & Zelniki & Selnike & Selnike \\
\hline
\end{tabular}

*Place names are written in capital letters and church names in italics. All other names are categorized as field names.

in Figures 2 and 3, the boundaries of field name units almost completely match the boundaries between different land use categories, as they were recorded in the Franciscan Cadaster, while contemporary land use is much more scattered and does not follow boundaries between field name units. But in spite of the fact that land use has significantly changed, the structure of field names, as well as the names themselves have both been preserved.

An interesting fact which should be noted at this point and will be discussed in detail in following subchapters is, that although the majority of field names are derived from physical characteristics of the area, field names do not always reflect a landscape's present condition (Sousa and García-Murillo 200I). Many names, especially those which describe land use, refer to a past landscape at the time when it was named. So, it is not uncommon for a meadow or even a forest to be called "field" (Široke niive/Wide fields, Dolge njive/Long fields, Male njive/Small fields, Zevniki/Cabbage fields), indicating changes in land use from the time when an area was named until the present. 


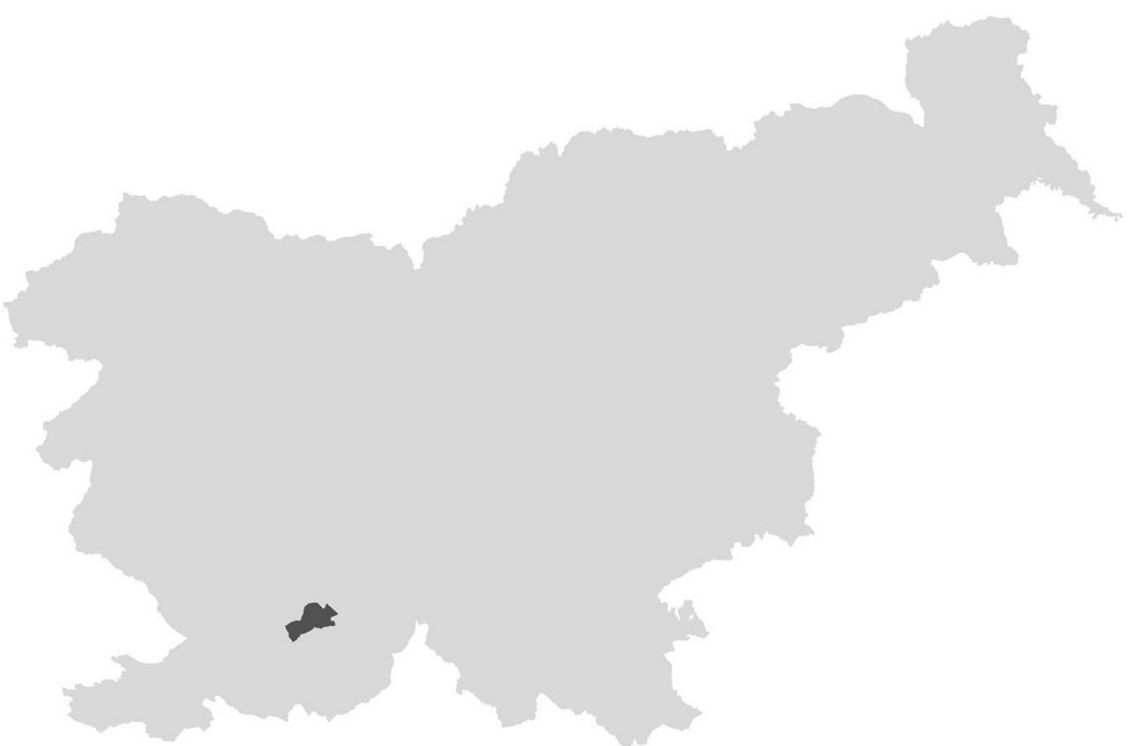

FIGURE 1 Research area. (Data sources: State border, Digital cadastral maps, both retrieved from The surveying and mapping Authority of the Republic of Slovenia-GURS)

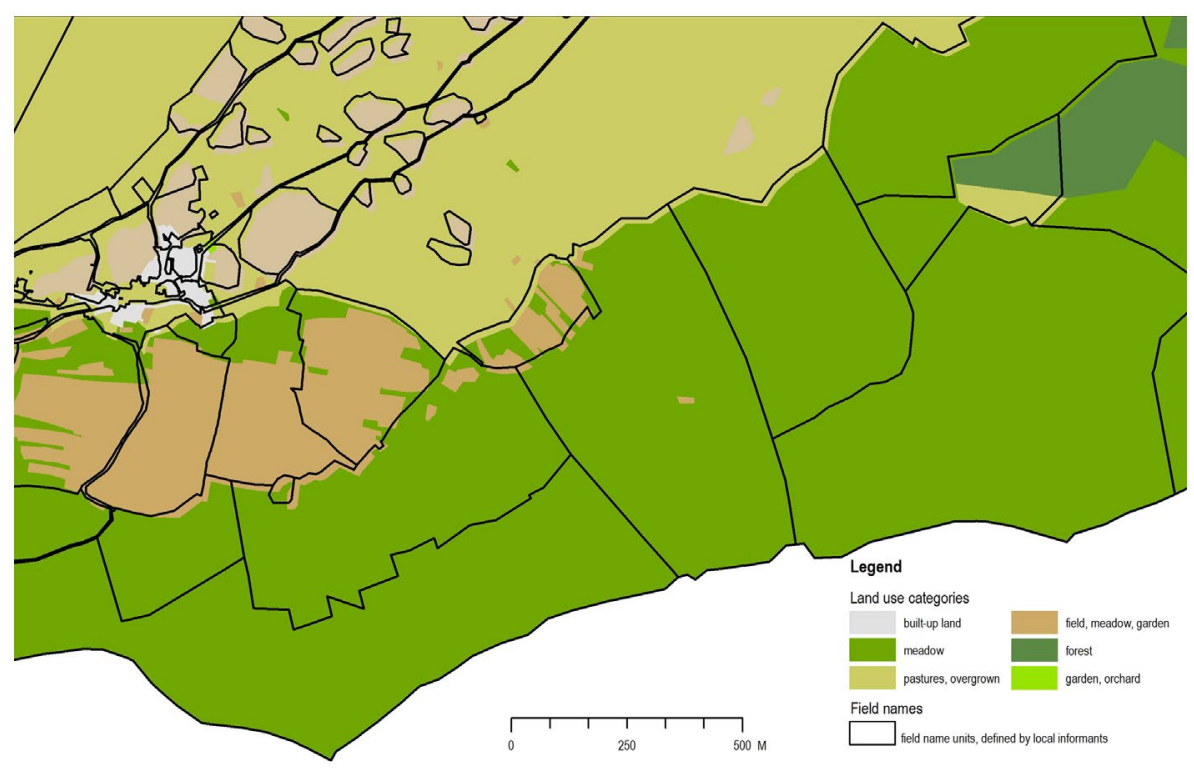

FIGURE 2 Land use around 1820 and contemporary structure of field names, as were delineated by the help of local informants - detailed view. (Data sources: Digital cadastral map, retrieved from GURS; Franciscan Cadastre of cadastral community Jurišče - retrieved from the Archive of the Republic of Slovenia) 


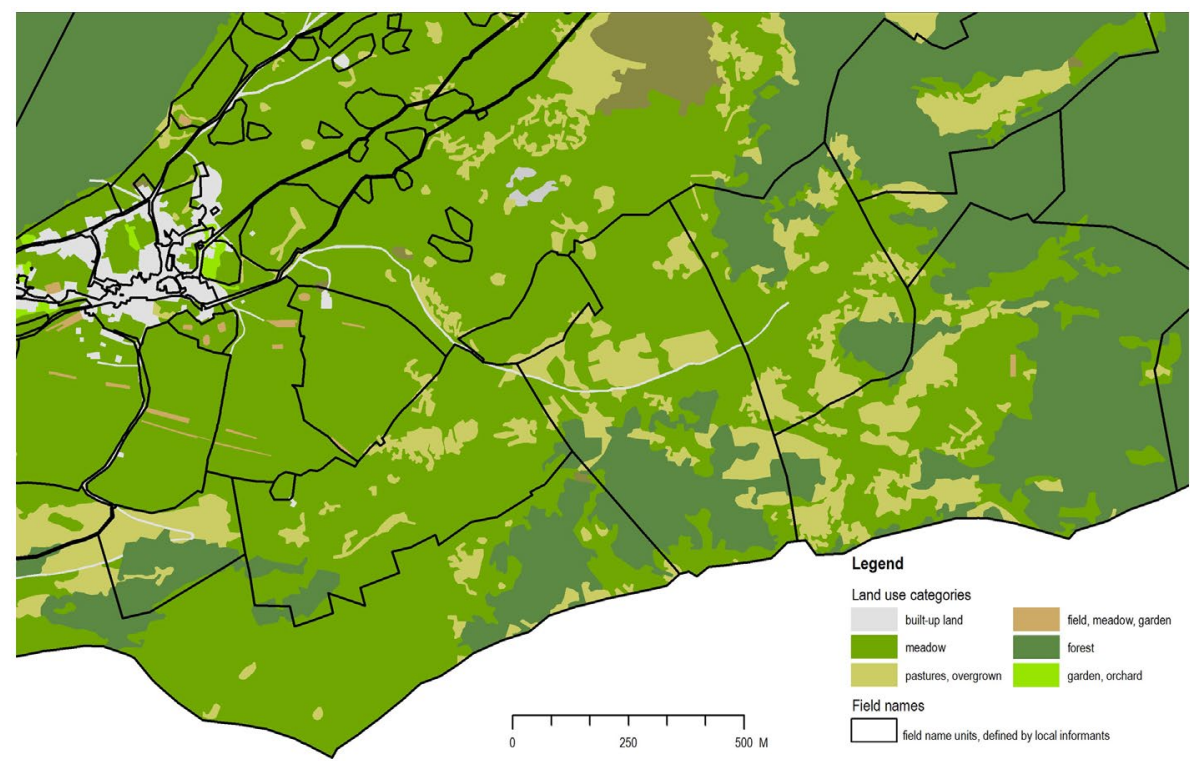

FIGURE 3 Land use in 2016 and contemporary structure of field names, as were delineated by the help of local informants - detailed view. (Data sources: Digital cadastral map, retrieved from GURS; land use map, retrieved from the Ministry of Agriculture, Forestry and Food)

\section{Field names and landscape character}

Like many authors who have researched place names and field names have ascertained, identical names often appear in several locations (Ilešič I950; Stewart, Keith, and Scottie 2004). However, the fact that they are known and used only by local inhabitants within a relatively closed social community, prevents misunderstandings in communication. Stewart, Keith, and Scottie (2004), who researched Inuit toponyms, found that names like tabiq/lake or qamaniq/river widening appear throughout the Arctic, but they only make sense in relation to knowledge of a homeland. The same fact can be observed for field names, especially in relation with the field division system. Names like Velike njive/Large fields or Dolge njive/Long fields were often used for naming the oldest and the most fertile village field (Ilešič I950), while name Male njive/Small fields is much more frequent in the karstic landscape, where field division is adjusted to terrain and parcels are much smaller (Titl I998). Equivalent field names appear within several cadastral communities that are also in our study area. Twenty-four names known by local informants appear in identical form, at least in two cadastral communities: field name Zevnik(i)/Cabbage field(s) appears five times in three cadastral communities; Senožet(i)/ Hay field(s) in all four cadastral communities; Doline/Valleys, Kot(i)/Corner(s), Zgon/ Cattle herding place, Žleb/Channel in three cadastral communities; Bregi/Banks, Borštl Forest, Cerkvenica/Church's land, Dol(i)/Pit(s), Devci/Parts, and few others in two cadastral communities. The interviews with local informants have shown that the majority of people know names within their local community, so there are no misunderstandings in communication. 
Since many names are derived from a landscape's physical characteristics, one would expect that places, which are named with identical names would also have similar landscape character. Our research has shown that this is not necessarily true. Clustering field name units on the basis of their characteristics (e.g. slope, land use, land division, landscape features, etc.) into groups of similarities has resulted in four groups with distinctive landscape character: ${ }^{4}$

(I) Fields and meadows on flat terrain;

(2) Karst meadows on undulating terrain, crisscrossed with hedges;

(3) Pastures; and

(4) Forest.

Field name units which cluster into the same group are similar according to their landscape characteristics. Table 3 shows identical names, which appear within at least two cadastral communities and their distribution within four groups - landscape character types. Out of twenty-four names, only seven are always classified into the same landscape character group (written in bold capital letters), while all other names classify at least into two different groups, which means that they differ in terms of landscape characteristics.

TABLE 3

IDENTICAL FIELD NAMES, WHICH APPEAR IN SEVERAL CADASTRAL COMMUNITIES AND THEIR CLASSIFICATION INTO GROUPS OF SIMILARITIES (LANDSCAPE CHARACTER TYPES)

\begin{tabular}{|c|c|c|c|c|c|}
\hline \multirow[b]{2}{*}{$\begin{array}{l}\text { Field names which appear in } \\
\text { several cadastral communities }\end{array}$} & \multirow[b]{2}{*}{$\begin{array}{l}\text { Number of } \\
\text { repetitions }\end{array}$} & \multicolumn{4}{|c|}{ Number of field name units, classified into each group } \\
\hline & & $\begin{array}{c}1 \text { Fields and } \\
\text { meadows }\end{array}$ & $\begin{array}{c}2 \text { Karst } \\
\text { meadows }\end{array}$ & 3 Pastures & 4 Forest \\
\hline Bregi & 2 & & 1 & 1 & \\
\hline BORŠT & 2 & & & & 2 \\
\hline Cerkvenica & 3 & & & 2 & 1 \\
\hline DOL/DOLI & 2 & & 2 & & \\
\hline Devci & 2 & 1 & 1 & & \\
\hline Doline & 3 & & 2 & & 1 \\
\hline Gradišče & 2 & & 1 & 1 & \\
\hline GRMADA & 2 & & & 2 & \\
\hline Hrib & 2 & & 1 & 1 & \\
\hline Pod Hribom & 2 & 1 & 1 & & \\
\hline Klančič/Klančiči & 2 & & 1 & 1 & \\
\hline Kot/Koti & 3 & 2 & 1 & & \\
\hline LOKA/LOKE & 2 & & & 2 & \\
\hline Plahute/Plehute & 2 & 1 & 1 & & \\
\hline Plešivec/Plešivica & 2 & & & 1 & 1 \\
\hline KRAŠKA REBER/KRAŠKE REBRI & 2 & & 2 & & \\
\hline Rebrnice & 2 & 1 & & & 1 \\
\hline Senožet/Senožeti & 4 & & 1 & 2 & 1 \\
\hline Ulovka/Ulovke & 2 & 1 & & & 1 \\
\hline Za vrti & 2 & & 1 & 1 & \\
\hline VRTOVI & 2 & & 2 & & \\
\hline Zevnik/Zevniki & 5 & 2 & & 3 & \\
\hline ZGON & 3 & & 3 & & \\
\hline Žleb/Žlebi & 4 & & 3 & 1 & \\
\hline
\end{tabular}


At this point it should be noted, that in spite of the fact that the majority of names originate in landscape's physical character, that doesn't simply lead to conclusion that the areas, named by similar names are similar also in terms of their landscape characteristics. Each area is always named with the reference to its surrounding: in the relatively flat valley bottom, a slightly inclined area is named Breg/Slope, while on much steeper terrain that same name is reserved only for the steepest slopes. As shown in Figure 4, the field name Zevniki/Cabbage fields is being used for describing two completely different locations in terms of its natural condition - one on the flat terrain in the valley bottom, and the other on the undulating karstic terrain, where a relatively flat sinkhole bottom with deeper soil enabled more intensive cultivation compared to its surroundings.

\section{Field names and land use change}

The third topic, discussed in this article is the question how field names, which have proven to be rather permanent, respond to land use change. As it was already mentioned, toponyms - especially those that refer to land use, often reflect the character of landscape in the time when it was named. To investigate how land use change is reflected in names, only the names which indicate land use have been selected from a comprehensive field name list. Fifty-four names have been selected among three hundred and seven field names that are defined by local informants. These names could be classified into three groups:

(I) Names, derived from nouns "njiva" (field) or "zevnik" (cabbage field). Traditionally, these areas were a combination of arable and fallow land;
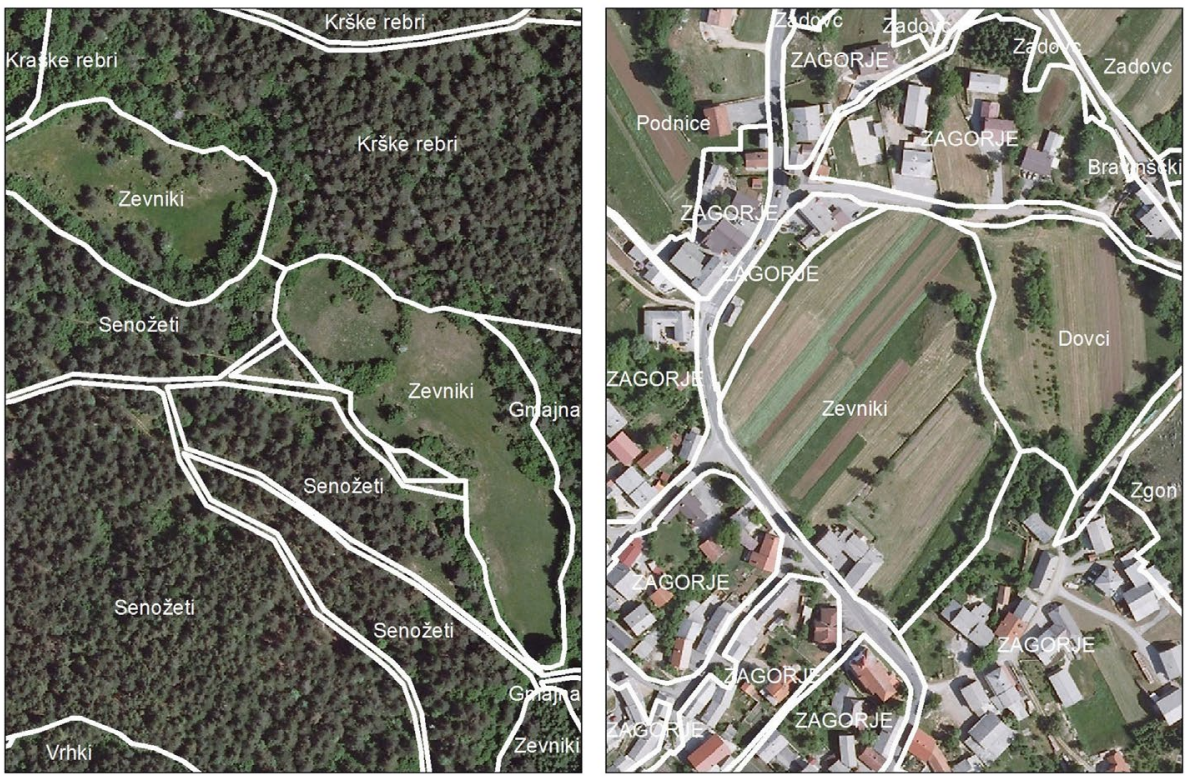

FIGURE 4 Field name Zevniki/Cabbage fields in two cadastral communities. (Data source: Digital orto-photo, retrieved from GURS) 
(2) Names, derived from nouns "senožet" (hayfield), "gmajna" (common) and "laz" (forest clearing). These areas were either used as pastures, either for harvesting firewood and/or strewing;

(3) Names derived from noun "vrt" (garden). Vegetable gardens on the outskirts of villages, but also small areas within commons where more fertile soil enabled cultivation (e.g. in the sinkholes) were usually named "vrt."

For each of these fifty-four units, land use change between I820 and 2016 was analyzed. Since the Franciscan Cadaster and contemporary land use map classify land use slightly differently, we introduced common, and simplified categories. This enabled a comparison between the two data sources that have been introduced in the first place: (a) built-up land; (b) meadows; (c) pastures and overgrown land; (d) combination of fields, meadows, and gardens; (e) forest; and ( $\mathrm{f}$ ) a combination of gardens and orchards.

As shown in Figure 5, the most obvious trend within all three groups is extensification. The combination of arable and fallow land, characteristic for fields has decreased from $58.9 \%$ in I 820 to $3.1 \%$ in 2016 . Gardens are similar to fields in terms of land use, as well as landscape change: the average percentage of arable land has decreased to less than $2 \%$, whereas the share of meadows has almost doubled - from $33.9 \%$ to $64.5 \%$. At the same time, more than a quarter of these areas are overgrown with forests. The third selected group: meadows, hayfields, and forest clearings, with $80 \%$ of pastures and meadows in I820, has also been significantly overgrown with forests: from $17.5 \%$ in 1820 to $65.6 \%$ in 2016 .

In Figure 6, land use change in six units, where the most extensive changes were evidenced within the group "field" is shown. Prevailing land use (more than $80 \%$ within all six units) in 1820 was a combination of arable and fallow land, but it decreased to

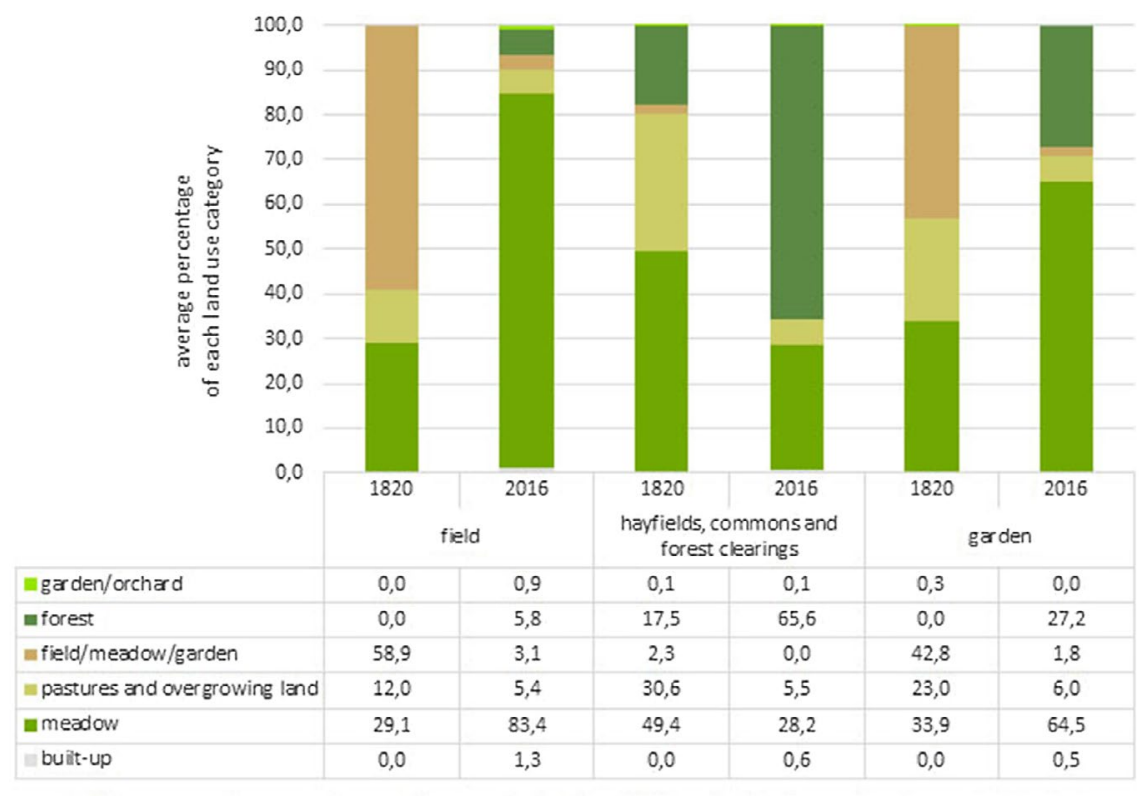

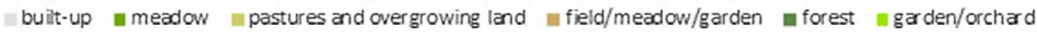




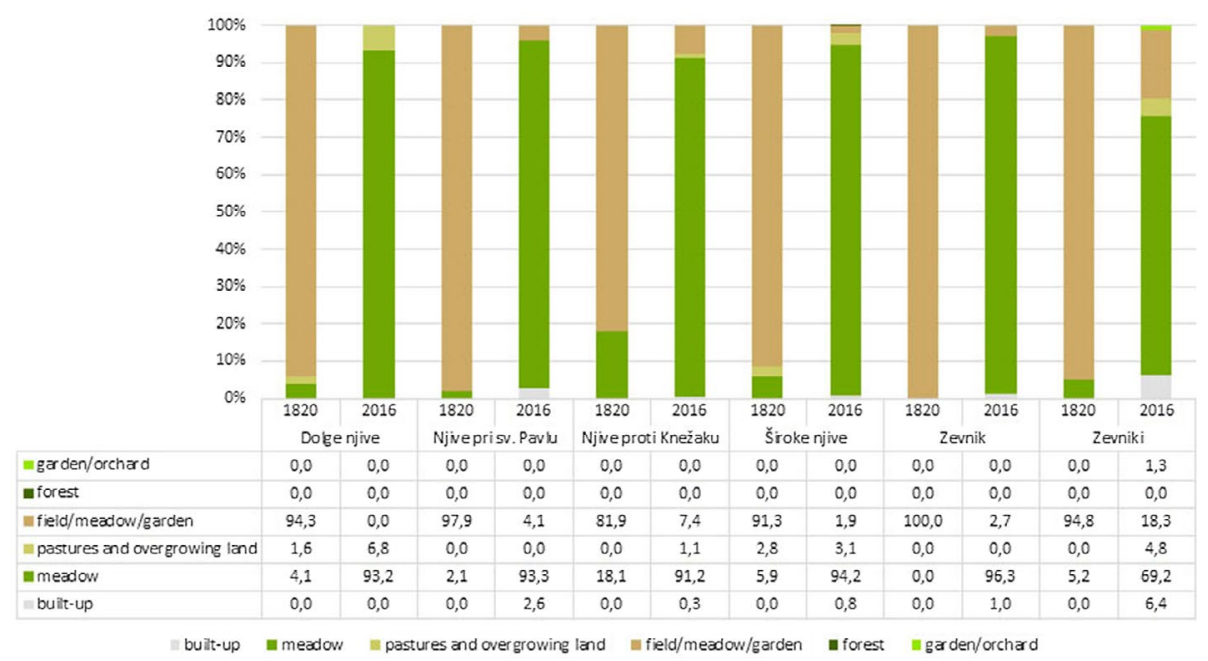

FIGURE 6 Land use change between 1820 and 2016 for selected field names 'njiva' (field) and 'zevnik' (cabbage field)

less than $20 \%$ (in five of six units even less than I0\%) by 2016 , when in five of six units more than $90 \%$ of the area was covered by meadows.

In spite of extensive land use change, field names, which indicate land use, have been preserved and reflect past land use. The majority of these field names were not even recorded on historical maps, but the fact that they refer to a land use category from that period leads us to assume that they were probably used already in the beginning of igth century.

\section{Conclusion}

A cultural landscape is filled with names which enable orientation and communication among members of a certain social community, indicate ownership, as well as describe the natural character of named places and/or human interventions that have reshaped these places. Among all names, field names express the most detailed knowledge about the landscape, since, jointly with the named places, they offer insight into human perception, understanding, and conceptual organization of the landscape.

Three interconnected aspects of field names have been discussed in this paper: (I) their temporal "behavior," (2) their relation to landscape character of named places, and (3) their connection to land use and land use change.

Considering the fact that landscapes are continuously changing phenomena, and field names are people's interpretation of physical space, one would expect that they change when different social relations, cultivation techniques, management practices, intensity of cultivation, etc. are introduced. Surprisingly, the presented research has proven that a relatively high share (around one fifth) of field names have been preserved for almost 200 years, while these names have been recorded in at least one historical and one contemporary source. Besides that, we can presume for many other names that are being used nowadays - especially those which are derived from land use categories - were 
used already at the beginning at the I9th century. However, they were not recorded on maps, while they reflect land use in that period and not present land use. As such, field names could be used as an evidence of land use change - toponyms are in many cases a reflection of land use at the time when the landscape was settled and named (Sousa and García-Murillo 200I) and they can be seen as historical documents of landscape dynamics or changes in land use (Conedera et al. 2007). The fact that many field names are not registered on any official map (as can be seen in Table I, only two hundred and fourty-two field names are recorded on a topographic map, while three hundred and seven names have been recorded with the help of local informants) does not make them more short-lived or ephemeral. Quite the contrary, it makes them even more persistent. Being used only locally within a relatively closed social community, they are not subject to change by political pressures. As Titl (2000) emphasizes, when Italians occupied Slovenian territory after World War I, they changed all personal names and place names, but not field names, which have remained mainly untouched. Political renaming is in general applied to established places of great importance (Azaryahu and Golan 200I; David 2OII).

Although physical environment is one of the strongest motives for naming and many identical names are repeated throughout the research area that does not lead to a conclusion that similar names are used to name places with similar landscape characteristics. Only seven out of twenty-four names, which appear more than once within the area, show similar landscape characteristics. One of the reasons is the fact that each place is named with reference to its surrounding. On a relatively flat terrain, a slightly inclined area will be named Breg/Slope, or a small hill will be named Vrh/Peak, while in higher altitudes and on steeper terrain only the steepest slopes are entitled to the name Breg/Slope, and only the highest mountains "deserve" the name Vrh/Peak. The second reason that names do not always reflect landscape character is the fact that the latter is changing, whereas names are much more stable. Names like Dol/Pit, Loka/Wetland, and Kraška reber/Carstic hillside, which are derived from more stable landscape characteristics (in these cases geology, topography, and hydrology), show similar landscape character and are classified within the same group of similarity. In contrast, names like Zeunik/Cabbage field or Senožeti/Hayfields, which are derived from land use, do not show similar landscape character and are classified into different groups. This could be explained by the fact that land use (and consequently landscape character) of named places has changed from the time when they were named. Presumably, places, named with similar field names referring to land use, were much more alike at the time when the landscape was named and landscape character was actually reflected in field names.

This research has shown that, despite the fact that field names are not a visible or tangible landscape layer, they represent an inseparable part of every landscape and they reveal much information about the way people perceived, interpreted, and utilized their environment. Engraved, not only in physical environment, but also in individuals' and collective memory they are a connection between the present to the past.

\section{Notes}

r. Cadastral community is the basic unit of land cadaster. Land cadaster is a comprehensive register of land, containing the cartographic data (maps), as well as other attributes (e.g. ownership, land use). The term cadastral community as well as the division into communities was introduced in I82os when so-called 
Franciscan cadaster was established throughout the Austrian Empire. For each cadastral community a cadastral map with all parcels and land use categories was prepared.

2. A term field name unit was used to describe an area, which could be delineated on the basis of parcel (cadastral) boundaries and is usually containing several parcels, which are named with a single field name.

3. The cartographers were mostly German-speaking military officers, since the research area was a part of Austrian Empire at the time of cadastral survey.

4. Results from the aforementioned $\mathrm{PhD}$ thesis have been used to research the relation among names and landscape character of named places. Each field name unit was described with the series of variables, which are shaping landscape character: elevation, aspect, slopes, and land use. Each field name unit was additionally attributed with a set of binary variables: microrelief features, the type and the position of trees and shrubs within unit, the size and the shape of parcels. On the basis of selected variables, which determine landscape character, field name units were clustered into groups of similarities using Gower's distance to measure dissimilarity between units. The results are published in: Penko Seidl, Kastelec, and Kučan 2015.

5. Collecting strewing is a traditional practice of harvesting fallen leaves and dry grass in autumn to spread litter for cattle in winter months.

\section{Disclosure statement}

No potential conflict of interest was reported by the author.

\section{Bibliography}

Azaryahu, M., and A. Golan. 200I. "(Re)Naming the Landscape: The Formation of the Hebrew Map of Israel I949-I960." Journal of Historical Geography 27 (2): I78-I95. doi:https://doi.org/IO.I006/jhge.2001.0297.

Basso, K. I996. Wisdom Sits in Places: Landscape and Language among the Western Apache. Albuquerque, NM: University of New Mexico Press.

Boillat, S., E. Serrano, S. Rist, and F. Berkes. 20I3. "The Importance of Place Names in the Search of Ecosystem-like Concepts in Indigenous Societies: An Example from the Bolivian Andes.” Environmental Management 5I (3): 663-678. doi:https://doi.org/IO.1007/s00267-0I2-9969-4.

Conedera, M., S. Vassere, C. Neff, M. Meurer, and P. Krebs. 2007. "Using Toponymy to Reconstruct past Land Use: A Case Study of 'Brüsáda' (Burn) in Southern Switzerland.” Journal of Historical Geography 33 (4): 729-748. doi:https://doi.org/IO.IOI6/j.jhg.2006.II.002.

David, J. 20I I. "Commemorative Place Names - Their Specificity and Problems.” Names 59 (3): I99-2I4. doi:https:// doi.org/IO.II79/0027773IIXI308233II90074.

Gelling, M. (1978) 2010. Signposts to the Past: Place-Names and the History of England. Chichester: Phillimore \& Co. Hawkes, J. H. 200I. A Land. Boston, MA: Beacon Press.

Ilešič, S. I950. Sistemi poljske razdelitve na Slovenskem [Field Division Systems in Slovenia]. Ljubljana: Inštitut za geografijo.

Kadmon, N. 2000. Toponymy: The Lore, Laws and Language of Geographical Names. New York: Vintage Press.

Miller, E. J.W 1969. "The Naming of the Land in Arkansas Ozarks: A Study in Culture Process." Annals of the Association of American Geographers 59 (2): 240-25I. doi:https://doi.org/IO.IIII/j.I467-8306.I969.tboo668.x.

Penko Seidl, N. 2008. "Significance of Toponyms, with Emphasis on Field Names, for Studying Cultural Landscape." Acta Geographica Slovenica 48 (I): 33-56. doi:https://doi.org/Io.3986/AGS 48 IO2.

Penko Seidl, N. 20I 5. Možnosti uporabe poimenovanj prostora v načrtovanju in upravljanju krajine[Possible Uses of Toponyms in Landscape Planning and Management]. PhD diss.: University of Ljubljana.

Penko Seidl, N., D. Kastelec, and A. Kučan. 2015. "Between the Physical and Perceptual: Toponyms in Landscape Typology, Management and Planning.” Annales - Series Historia Et Sociologia 25 (3): 595-608.

Rose-Redwood, R., D. Alderman, and M. Azaryahu. 20I0. "Geographies of Toponymic Inscription: New Directions in Critical Place-Name Studies.” Progress in Human Geography 34 (4): 453-470. doi:https://doi. org/IO.II77/0309132509351042.

Sousa, A., and P. García-Murillo. 200I. "Can Place Names Be Used as Indicators of Landscape Changes? Application to the Doñana Natural Park (Spain).” Landscape Ecology I6 (5): 39I-406. doi:https://doi.org/Io. IO 23/A:IOI7585IOI389.

Stewart, G. R. (1945) 2008. Names on the Land: A Historical Account on Place-Naming in the United States. New York: New York Review Books. 
Stewart, A. M., D. Keith, and J. Scottie. 2004. "Caribou Crossing and Cultural Meanings: Placing Traditional Knowledge and Archaeology in Context in an Inuit Landscape." Journal of Archaeological Method and Theory II (2): I83-2II. doi: https://doi.org/I0.I023/B:JARM.0000038066.09898.cd.

Tent, J. 20I5. "Approaches to Research in Toponymy." Names 63, no. 2: 65-74. doi:https://doi.org/Io.II79/002777 3814Z.000000000103.

Thornton, T. F. I997. “Anthropological Studies of Native American Place Naming." American Indian Quarterly $2 \mathrm{I}$ (2): 209-228. doi:https://doi.org/I0.2307/II85645.

Tilley, C. I994. A Phenomenology of Landscape. Oxford/Providence: Berg Publishers.

Titl, J. I998. Geografska imena v severozahodni Istri [Geographical Names in Northwest Istria]. Koper: Zgodovinsko društvo za južno Primorsko.

Titl, J. 2000. Toponimi Koprskega Primorja in njegovaga zaledja [Toponyms of Koper Littoral and its Hinterland]. Koper: Zgodovinsko društvo za južno Primorsko.

Tuan, Y. F. I991. "Language and the Making of Place: A Narrative-Descriptive Approach." Annals of the Association of American Geographers 8I (4): 684-696. doi:https://doi.org/Io.IIII/j.I467-8306.I99I.tboI7I5.x.

\section{Notes on contributor}

Nadja Penko Seidl is a Teaching Assistant in the Department of Landscape Architecture, at the Biotechnical Faculty, University of Ljubljana, where she teaches courses in Landscape Evaluation, Landscape Planning, and Landscape Management. Her research interest focuses mostly on invisible and intangible aspects of cultural landscape, especially naming.

Correspondence to: Nadja Penko Seidl, University of Ljubljana, Biotechnical Faculty, Department of Landscape Architecture, Jamnikarjeva IoI, Iooo Ljubljana, SLOVENIA Email:nadja.penko@bf.uni-lj.si 